\title{
Manohar Mouli Biswas, Surviving in My World: Growing Up Dalit in Bengal
}

John Thieme

\section{Q OpenEdition}

1 Journals

Electronic version

URL: https://journals.openedition.org/ces/5644

DOI: $10.4000 /$ ces.5644

ISSN: 2534-6695

Publisher

SEPC (Société d'études des pays du Commonwealth)

\section{Printed version}

Date of publication: 1 April 2016

Number of pages: 135-137

ISSN: 2270-0633

\section{Electronic reference}

John Thieme, "Manohar Mouli Biswas, Surviving in My World: Growing Up Dalit in Bengal", Commonwealth Essays and Studies [Online], 38.2 | 2016, Online since 06 April 2021, connection on 01 July 2021. URL: http://journals.openedition.org/ces/5644 ; DOI: https://doi.org/10.4000/ces.5644

This text was automatically generated on 1 July 2021.

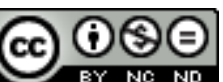

Commonwealth Essays and Studies is licensed under a Licence Creative Commons Attribution - Pas d'Utilisation Commerciale - Pas de Modification 4.0 International. 


\title{
Manohar Mouli Biswas, Surviving in My World: Growing Up Dalit in Bengal
}

\author{
John Thieme
}

\section{REFERENCES}

Manohar Mouli Biswas. Surviving in My World: Growing Up Dalit in Bengal. Trans. and ed. by Angana Dutta and Jaydeep Sarangi. Kolkata: Samya, 2015. xxxii +125 p. ISBN (pb): 978-93-81345-09-2. Rs 350

1 In recent years dalit writing has come to be an increasingly important part of the Indian literary mosaic and a movement that began in Maharashtra under the influence of Dr Ambedkar is now flourishing in Bengal, both in Bangladesh and West Bengal, though its wider readership remains reliant on translation. Manohar Mouli Biswas's Amar Bhubane Ami Benche Thaki (2013) is described in the Foreword of this edition as "one of the earliest" Bengali dalit autobiographies and "probably the first to be translated into English." Its translation, by Angana Dutta and Jaydeep Sarangi, Surviving in My World, represents a significant milestone on the road to making Bengali dalit writing more widely available and in so doing raising awareness of caste discrimination in Bengal.

In Latin America testimonio has played a vital role in the process of raising awareness of the predicament of the socially excluded and Surviving in My World offers a similar kind of testimonial witness, with its directness of style chronicling the "realities" of growing up in a namashudra (casteless Hindu) community in the Khulna district of Bangladesh (then East Pakistan). Biswas's chronicle of his early years is circumstantial. For the most part his syntax relies on main clauses ("Thakurda never wore shoes. He never had shoes"; "The nama community did not have the dowry system"; "We are a people of mud and water") and this makes the narrative seem like an unmediated account of the everyday hardships and struggles, along with the pragmatism and resil-ience of growing up dalit in such a community. The story is devoid of sentimentality and, in so 
far as it represents a protest against the discrimination suffered by dalits, it does so primarily through recording contingent detail in a matter-of-fact manner. An introductory note by the translators identifies the particular problems of rendering the idiolect of Biswas's temporally distant and localized world into English. The present reviewer is ill-equipped to judge how far they have succeeded in recapturing its distinctiveness, but they certainly provide a linguistically persuasive account of a nowremote community. One of the strategies they use to achieve this is the retention of words embodying concepts that are ultimately untranslatable into another language, and they supplement this with notes on the Bengali calendar, a list of kinship terms and a more general glossary.

3 The predominantly literal mode of the autobiography makes images, when they do appear, all the more striking, particularly since they emerge as a natural outcrop of the shared mentality of the namashudra community. This is the case with a trope that appears more than once - that of the water hyacinth:

This was a community that remained neglected away from the watch of the nation's administration. The people born in nature, lived in their own way and even died in their own way. The name of this history of life and death is prisnika - growing up like the water hyacinth and dying like it, uncared for.

In his introductory Author's Note, Biswas explains that prisnika, an "uncommon" Bengali word meaning "water hyacinth," was his initial title for the autobiography, but he changed this, because for him the plant is associated with neglect and pain, and he feels he has transcended such feelings through personal endeavour. Educational success has moved him into Kolkata's lower middle classes and in his adult career he has been a leading activist in the Bangla Dalit Sahitya Sanstha (Bengali Dalit Literature Association), publishing ten works of creative writing along with several jointly edited works on dalit issues. In the autobiography, though, he confines himself to his early years, only offering a glimpse of his later life in the last of his ten chapters. The suggestion is that chronicling the poverty, discrimination and hardship of dalit life is more important than writing a Western narrative of individual success such as one finds in American rags-to-riches tales. Autobiography in this incarnation - and it is typical of dalit life writing - is a communal, not a personal genre. Biswas speaks as the voice of his community.

Consequently it may seem inappropriate, when, towards the end of his account, he steps outside the circumscribed world he is depicting to as it were validate narrative elements through the use of literary analogies: his first sight of a train is linked with Apu and Durga's similar experience in Bibhutibhushan Bandyopadhyay's Pather Panchali, and he compares his jetha (father's elder brother) to the dalit carpenter Velutha in Arundhati Roy's The God of Small Things. Hitherto his world has been presented with an autonomous integrity that is devoid of such intertexts, but from the outset it has been a donnée that another world beckons: educational achievement can be a passport to success in society at large and the trajectory of his own career is a striking example of such advancement. To make this a major part of the autobiography would, though, be to move outside the assumptions that are central to the text. His own progress up the social ladder is an exception to the rule and restricting his narrative to his early years enables him to maintain a communal focus.

5 Nonetheless the appetites of those who may want to know more about what has happened to him subsequently are satisfied in the present volume by a fairly full interview, in which Biswas talks about his adult life in conversation with the two 
translators and Mohini Gurav. Some of his comments in the interview are devoted to listing the people, activities and publications of the Bengali Dalit Literature Association. This runs the risk of seeming like so much roll calling, but Biswas makes the point that oral testimony is quickly forgotten, so his inventories serve the purpose of providing a more permanent record of the projects, participants and events that have played their part in the struggle of Bengali dalits to emancipate themselves from the religionsanctioned caste hierarchies and exclusions enshrined in the Rig Veda and perpetuated by the Manusmriti (laws of Manu).

Other aspects of the interview are altogether more readable, not least passages in which Biswas talks about his experience in a post-Partition refugee camp in India, where the treatment of migrants was still determined by hierarchical caste classification. The interview is also notable for Biswas's assertion that the HinduMuslim schism that had such devastating consequences for the northern wings of the sub-continent at the time of Partition had previously been an irrelevance in his own community, which, placed as it was among the lowest of the Hindu low, co-existed harmoniously with its Muslim neighbours.

Overall the various sections that frame the actual autobiography - Author's Note, Introduction, Preface and the interview - serve to contextualize and broaden the circumstantial detail that characterizes Biswas's memoir. In the Author's Note, he draws analogies between the Dalit Panther movement founded in Mumbai in 1972 and the African American struggle for civil liberties. The parallels can be loose - he ranges from Lincoln's Emancipation Proclamation to the Black Panther movement in the 1960s - but the net effect is to extend the political sub-text that is always implicit in his account of the particularities of his experience of his growing up dalit in Bengal, so that, in addition to making a very specific contribution to the his own group's continuing endeavour to achieve social justice, they have a resonance that will echo with dispossessed peoples in many other parts of the globe.

\section{AUTHORS}

\section{JOHN THIEME}

John THIEME is a Senior Fellow at the University of East Anglia and previously held chairs at the University of Hull and London South Bank University. His books include Derek Walcott (Manchester UP, 1999), Post-Colonial Con-Texts (Continuum, 2001), Post-Colonial Studies: The Essential Glossary (Hodder Education, 2003) and R.K. Narayan (Manchester UP, 2007). He edited The Journal of Commonwealth Literature from 1992 to 2011 and is General Editor of the Manchester University Press Contemporary World Writers Series. 